Article

\title{
Efficacy from Different Extractions for Chemical Profile and Biological Activities of Rice Husk
}

\author{
Truong Ngoc Minh ${ }^{1}$ (D), Tran Dang Xuan ${ }^{1, *}$ (D), Ateeque Ahmad ${ }^{2}$, \\ Abdelnaser Abdelghany Elzaawely ${ }^{3}{ }^{(1)}$, Rolf Teschke ${ }^{4}$ and Truong Mai Van ${ }^{1}$ \\ 1 Graduate school for International Development and Cooperation, Hiroshima University, \\ Hiroshima 739-8529, Japan; minhtn689@gmail.com (T.N.M.); truongmaivan1991@gmail.com (T.M.V.) \\ 2 Chemical Engineering, CSIR, CIMAP, Kukrail Picnic Spot Road, Lucknow 226015, India; \\ ateeque97@gmail.com \\ 3 Department of Agricultural Botany, Faculty of Agriculture, Tanta University, Tanta 31527, Egypt; \\ elzaawely@agr.tanta.edu.eg \\ 4 Department of Internal Medicine II, Division of Gastroenterology and Hepatology, Klinikum Hanau, \\ Teaching Hospital of the Medical Faculty, Goethe University Frankfurt/Main, D-63450 Hanau, Germany; \\ rolf.teschke@gmx.de \\ * Correspondence: tdxuan@hiroshima-u.ac.jp; Tel./Fax: +81-82-424-6927
}

Received: 26 March 2018; Accepted: 25 April 2018; Published: 27 April 2018

check for updates

\begin{abstract}
Rice husk is a by-product produced abundantly in rice production but it has low commercial value and causes environmental pollution. This study was conducted to examine different extracting solvents and conditions to optimize the efficacy of antioxidant and antimicrobial potentials, and chemical components in rice husk. By the use of distilled water at $100{ }^{\circ} \mathrm{C}$, the ethyl acetate (EtOAc) extract was potent in both total phenolic content (TPC), total flavonoid content (TFC), and DPPH scavenging activity. The treatment of either ethyl acetate $\left(100{ }^{\circ} \mathrm{C}, 1 \mathrm{~h}\right)$, combined with $\mathrm{MeOH} 100 \%$, showed the highest percent of lipid peroxidation inhibition (LPI) (86\%), meaning that the strongest antioxidant activity was by the $\beta$-carotene bleaching method. The treatment of distilled water at room temperature possessed the strongest antioxidant activity in the assay of the reducing power. The use of dried samples at $100{ }^{\circ} \mathrm{C}$ for $2 \mathrm{~h}$, combined with methanol $(\mathrm{MeOH})$ $10 \%$, provided the most potent antimicrobial activities against Escherichia coli, Klebsiella pneumoniae, Listeria monocytogenes, Bacillus subtilis, and Proteus mirabilis. The results suggested that the EtOAc extract from rice husk could be a potential source of natural antioxidants. In general, the use of temperature $100{ }^{\circ} \mathrm{C}$ for $2 \mathrm{~h}$, combined with either EtOAc or $10 \% \mathrm{MeOH}$, can optimize chemical components and antioxidant and antimicrobial capacities in rice husk. Principal constituents putatively identified by gas chromatography-mass spectrometry (GC-MS) revealed the presence of momilactones A and B (MA and MB, respectively), phenols, phenolic acids, and long-chain fatty acids, although yields of these compounds varied among extracts. The bioactive MA and MB were found in most of the extracts, except distilled water and $\mathrm{MeOH} \leq 50 \%$, at any temperature. Findings of this study provided optimal conditions for future production at an industrial scale for rice husk to exploit its potent biological properties. It thus helps to increase the economic value and reduce the disposal burden and environmental troubles caused by rice husk.
\end{abstract}

Keywords: rice husk; antimicrobial activity; antioxidant activity; phenolics; total phenols; total flavonoids

\section{Introduction}

Rice husk is an agricultural waste that farmers have experienced difficulties in disposing of in large quantities. The annual output of rice husk worldwide is about 120 million tons [1]. 
Rice husk is traditionally disposed of in landfills, and has recently been used for electricity generation, but simultaneously a large number of greenhouse gases are being produced [2]. Rice husk contains a high percentage of silica (15-20\%) [3] and lignin (20\%) [3], which cause obstacles in processing and exploiting potential uses of rice husk. Others are cellulose (35\%), hemicellulose (25\%), crude protein $(2 \%)$, and ash (17\%) [3], thus it is a challenge to develop rice husk to be a value-added byproduct, as it has hard surface, high silica content, small bulk density, and is not easily fermented by bacteria. In addition, the emission of rice husk ash has received social criticisms and complaints because of the associated carcinogenic and bio-accumulative effects [2]. Rice husk does not show a remarkable commercial interest, and its price is very low (30-40 euro/ton in Europe) [4], and 25 USD/ton in India [5]. Rice husk has elevated ash and lignin contents, thus it is not appropriate to use as animal feed raw material. Rice husk has been reported to be a potential source for bioethanol production [1]; furfural, one of the top value bio-based chemicals, has been recently synthesized from rice husk $[2,6]$. However, the manufactured price appears to be difficult for consumption in markets because of its non-competitive price, as compared to another renewable source.

Rice husk can be burned under controlled conditions to achieve a large amount of silica (approximately $95 \%$ of the total ash content), and is applicable in building materials, adsorbent phase for the treatment of waste water, solid phase for supported enzymes, and filters $[7,8]$. Recent efforts have used $\mathrm{H}_{2} \mathrm{SO}_{4}$ [3,9], $\mathrm{ZnCl}_{2}$ and $\mathrm{H}_{3} \mathrm{PO}_{4}$ [10,11], and $\mathrm{KOH}$ [12] and $\mathrm{NaOH}$ [13] as the pre-treatment chemicals to prepare D-xylose and activated carbon in rice husk. However, in view of the environmental perspective, the use of these chemicals is not preferred. The establishment of a safe, convenient, and effective extraction to utilize the potential of rice husk is required.

There are several well-known biochemicals in rice husk such as momilactones which play a role as plant growth inhibitors [14-18], and are involved in drought and salinity tolerance in rice [19]. 4-Hydroxybenzoic acid and trans-4-hydroxycinnamic acid were identified from rice husk and showed antimicrobial potential [20]. Glycosyl flavonoid [21,22] and phytic acid [23] in Katakuhara cutivar, and 2,3,6-trimethylanisole (anisole); $m$-hydroxybenzaldehyde; 4-hydroxy-3-methoxybenzaldehyde (vanillin); and 4-hydroxy-3,5-dimethoxybenzaldehyde (syringaldehyde) in wild rice have been reported as antioxidants in rice husk. The polysaccharide fraction was useful for various applications, such as adhesives, films, and biofuel production [24]. Rice husk has been described as exhibiting weed-suppressing abilities [25-27].

In order to explore further potential use of rice husk and provide a positive measure to reduce the environmental problems caused by this rice by-product, this study was conducted to examine total phenolic content (TPC), total flavonoid content (TFC), antioxidant (DPPH radical scavenging activity, $\beta$-carotene bleaching method, and reducing power), and antimicrobial (Escherichia coli, Klebsiella pneumoniae, Listeria monocytogenes, Bacillus subtilis, and Proteus mirabilis) activities of rice husk. In order to enhance the commercial value of rice husk, different extracting solvents, temperatures, and pressures on optimization of chemical components, and antioxidant and microbial activities were investigated.

\section{Materials and Methods}

\subsection{Preaparation of Rice Husks and Extracts}

Rice husks (subtype: Japonica; var. Koshihikari) were collected from rice mills in Saijo area, close to Hiroshima University, Higashi Hiroshima, Japan, in August 2017. An amount of $200 \mathrm{~g}$ dried rice husk was used in each of the extraction methods as described in Table 1. Briefly, experiments were designed by immersing samples in a volume of $1 \mathrm{~L}$ of different solvents $(\mathrm{MeOH} 10,30,50,70,100 \%$ and distilled water, respectively) under various temperature conditions (room temperature, $100{ }^{\circ} \mathrm{C}$, boiled or dried, $1-4 \mathrm{~h}$ ) and pressure $(120 \mathrm{kPa})$. Each extract was concentrated under reduced pressure at $30^{\circ} \mathrm{C}$. The obtained crude extracts were dissolved in distilled water and successively partitioned 
with hexane and ethyl acetate. The hexane supernatants were removed, and all the ethyl acetate extracts (M1-M26) were kept in the dark at $5{ }^{\circ} \mathrm{C}$ for further analysis.

Table 1. Yields of the ethyl acetate (EtOAc) extracts.

\begin{tabular}{|c|c|c|}
\hline Methods & Codes & EtOAc Crude Extract (g) \\
\hline $\mathrm{MeOH} 100 \%$ & M1 & $0.5 \pm 0.004$ \\
\hline $\mathrm{MeOH} \mathrm{70 \%}$ & M2 & $0.46 \pm 0.04$ \\
\hline $\mathrm{MeOH} 50 \%$ & M3 & $0.12 \pm 0.01$ \\
\hline $\mathrm{MeOH} \mathrm{30 \%}$ & M4 & $0.097 \pm 0.007$ \\
\hline $\mathrm{MeOH} \mathrm{10 \%}$ & M5 & $0.099 \pm 0.001$ \\
\hline Distilled water (room temperature) & M6 & $0.040 \pm 0.001$ \\
\hline Distilled water $\left(100^{\circ} \mathrm{C}\right)$ & M7 & $0.012 \pm 0.001$ \\
\hline Distilled water $\left(100^{\circ} \mathrm{C}, 30 \mathrm{~min}\right)+\mathrm{MeOH} 100 \%$ & M8 & $0.067 \pm 0.004$ \\
\hline Distilled water $\left(100{ }^{\circ} \mathrm{C}, 30 \mathrm{~min}\right)+$ EtOAc $100 \%$ & M9 & $0.5 \pm 0.03$ \\
\hline Distilled water $\left(100{ }^{\circ} \mathrm{C}, 1 \mathrm{~h}\right)+\mathrm{MeOH} 100 \%$ & M10 & $0.446 \pm 0.02$ \\
\hline Distilled water $\left(100^{\circ} \mathrm{C}, 2 \mathrm{~h}\right)+\mathrm{MeOH} 100 \%$ & M11 & $0.5 \pm 0.009$ \\
\hline Distilled water $\left(100^{\circ} \mathrm{C}, 3 \mathrm{~h}\right)+\mathrm{MeOH} 100 \%$ & M12 & $0.5 \pm 0.02$ \\
\hline Distilled water $\left(100{ }^{\circ} \mathrm{C}, 4 \mathrm{~h}\right)+\mathrm{MeOH} 100 \%$ & M13 & $0.5 \pm 0.01$ \\
\hline Dried $\left(100^{\circ} \mathrm{C}, 1 \mathrm{~h}\right)+\mathrm{MeOH} 100 \%$ & M14 & $0.45 \pm 0.03$ \\
\hline Dried $\left(100{ }^{\circ} \mathrm{C}, 1 \mathrm{~h}\right)+\mathrm{MeOH} 70 \%$ & M15 & $0.4 \pm 0.02$ \\
\hline Dried $\left(100^{\circ} \mathrm{C}, 1 \mathrm{~h}\right)+\mathrm{MeOH} 50 \%$ & M16 & $0.168 \pm 0.02$ \\
\hline Dried $\left(100{ }^{\circ} \mathrm{C}, 1 \mathrm{~h}\right)+\mathrm{MeOH} 30 \%$ & M17 & $0.058 \pm 0.001$ \\
\hline Dried $\left(100{ }^{\circ} \mathrm{C}, 1 \mathrm{~h}\right)+\mathrm{MeOH} 10 \%$ & M18 & $0.193 \pm 0.03$ \\
\hline Dried $\left(100{ }^{\circ} \mathrm{C}, 1 \mathrm{~h}\right)+$ distilled water (room temperature) & M19 & $0.162 \pm 0.04$ \\
\hline Dried $\left(100^{\circ} \mathrm{C}, 1 \mathrm{~h}\right)+$ distilled water $\left(100^{\circ} \mathrm{C}\right)$ & M20 & $0.620 \pm 0.04$ \\
\hline Dried $\left(100^{\circ} \mathrm{C}, 1 \mathrm{~h}\right)$, distilled water $\left(100^{\circ} \mathrm{C}, 1 \mathrm{~h}\right)+\mathrm{MeOH} 100 \%$ & M21 & $0.314 \pm 0.01$ \\
\hline Dried $\left(100^{\circ} \mathrm{C}, 2 \mathrm{~h}\right)$, distilled water $\left(100^{\circ} \mathrm{C}, 2 \mathrm{~h}\right)+\mathrm{MeOH} 100 \%$ & M22 & $0.5 \pm 0.03$ \\
\hline Dried $\left(100^{\circ} \mathrm{C}, 3 \mathrm{~h}\right)$, distilled water $\left(100^{\circ} \mathrm{C}, 3 \mathrm{~h}\right)+\mathrm{MeOH} 100 \%$ & M23 & $0.6 \pm 0.02$ \\
\hline Dried $\left(100^{\circ} \mathrm{C}, 4 \mathrm{~h}\right)$, distilled water $\left(100^{\circ} \mathrm{C}, 4 \mathrm{~h}\right)+\mathrm{MeOH} 100 \%$ & M24 & $0.4 \pm 0.02$ \\
\hline Distilled water $\left(100{ }^{\circ} \mathrm{C}, 120 \mathrm{kPa}\right)+\mathrm{MeOH} 100 \%$ & M25 & $0.4 \pm 0.02$ \\
\hline Dried $\left(100{ }^{\circ} \mathrm{C}, 120 \mathrm{kPa}\right)+\mathrm{MeOH} 100 \%$ & M26 & $0.5 \pm 0.05$ \\
\hline
\end{tabular}

Values are means $\pm \mathrm{SD}$ (standard deviation) $(n=3)$.

\subsection{Determination of Total Phenolic Content (TPC)}

The total phenolic content assay was conducted using the Folin-Ciocalteu method as described in previous studies [28,29] with minor modifications. An aliquot of $200 \mu \mathrm{L}$ of each sample $(0.5 \mathrm{mg} / \mathrm{L}) \mathrm{was}$ mixed $1.0 \mathrm{~mL}$ of a 10-fold diluted Folin-Ciocalteu's reagent in distilled water and $0.8 \mathrm{~mL}$ of $7.5 \mathrm{wt} \%$ aqueous sodium carbonate solution, respectively. The obtained solutions were incubated in the dark for $30 \mathrm{~min}$ at room temperature. Blanks were prepared by adding $99.8 \% \mathrm{MeOH}$ in the same manner with samples. The absorbance was measured at $765 \mathrm{~nm}$ using a HACH DR/4000U spectrophotometer (HACH Company, Loveland, CO, USA). The TPC evaluation was then assessed on the basis of a standard calibration curve $\left(\mathrm{r}^{2}=0.9933\right)$ using gallic acid as a standard $(10,25,50$, and $100 \mathrm{ppm})$. The TPC value was expressed as mg of gallic acid equivalent per gram dry weight (mg GAE/g dry weight (DW)).

\subsection{Determination of Total Flavonoid Content (TFC)}

The total flavonoid content in EtOAc extracts was determined spectrophotometrically using the method described by Quettier-Deleu et al. [30]. A volume of $0.5 \mathrm{~mL}$ of sample extract was mixed with $0.5 \mathrm{~mL}$ of $2 \%$ aluminum chloride-methanol solution. $\mathrm{MeOH}(99.8 \%)$ was used as the blank in this assay. After $15 \mathrm{~min}$ at room temperature, the mixtures were measured at the absorbance of $430 \mathrm{~nm}$ using a spectrophotometer (HACH Company, Loveland, CO, USA). The TFC was expressed as mg of rutin equivalent per gram dry weight (mg RE/g DW). 


\subsection{Antioxidant Properties}

\subsubsection{DPPH Radical Scavenging Activity}

The antioxidant activity of the EtOAc extracts was determined according to the 2, 2-Diphenyl1-picrylhydrazyl (DPPH) free radical scavenging method described by Elzaawely and Tawata [31]. Briefly, an aliquot of $0.5 \mathrm{~mL}$ sample extracts was mixed with $0.25 \mathrm{~mL}$ of $0.5 \mathrm{mM}$ DPPH and $0.5 \mathrm{~mL}$ of $0.1 \mathrm{M}$ acetate buffer ( $\mathrm{pH}$ 5.5). The mixtures were incubated for $30 \mathrm{~min}$ in the dark, at room temperature. The absorbance was read at $517 \mathrm{~nm}$ using a spectrophotometer (HACH DR/4000U-Hach company, Loveland city, CO, USA). The control used in this assay was DPPH (1000 ppm) in a test tube and the blank was $99.8 \% \mathrm{MeOH}(1 \mathrm{~mL})$. The percentage of the DPPH radical scavenging activity was calculated using the following formula:

$\%$ DPPH radical scavenging activity $=100 \times\left[\left(\mathrm{A}_{0}-\mathrm{A}_{1}\right) / \mathrm{A}_{0}\right]$

where $\mathrm{A}_{0}=$ absorbance of control, $\mathrm{A}_{1}=$ absorbance of sample. The results were interpreted as $50 \%$ inhibition concentration ( $\mathrm{IC}_{50}$ ) values expressed in ppm (concentration in parts per million). The lower $\mathrm{IC}_{50}$ value indicates higher DPPH radical scavenging activity. All measurements were performed in triplicate.

\subsubsection{Determination of Antioxidant Activity with the $\beta$-Carotene Bleaching Test}

The $\beta$-carotene bleaching assay was performed as described by Xuan et al. [32] with some modifications. An amount of $2 \mathrm{mg}$ of $\beta$-carotene/linoleic acid was initially prepared by dissolving in $10 \mathrm{~mL}$ of chloroform. An aliquot of the $\beta$-carotene solution $(1.5 \mathrm{~mL})$ was added to $20 \mathrm{mg}$ of linoleic acid and $200 \mathrm{mg}$ of Tween-40. After chloroform was evaporated under vacuum at $45^{\circ} \mathrm{C}$, an amount of $50 \mathrm{~mL}$ pure oxygenated water was added and shaken vigorously to form an emulsion. A methanolic solution of $0.12 \mathrm{~mL}$ of sample extracts was mixed with $1 \mathrm{~mL}$ of the emulsion. Methanol was used as a control. The solutions were incubated at $50{ }^{\circ} \mathrm{C}$ and recorded at $492 \mathrm{~nm}$ using a spectrophotometer (HACH DR/4000U-Hach company, Loveland city, CO, USA). All extracts were measured at zero time and every $30 \mathrm{~min}$ up to $180 \mathrm{~min}$. The assay was carried out in triplicate for each extract. Lipid peroxidation inhibition (LPI) was calculated using the following formula:

$$
\text { LPI }(\%)=\mathrm{A}_{1} / \mathrm{A}_{0} \times 100
$$

where $A_{0}=$ absorbance value measured at zero time for the test sample, $A_{1}=$ corresponding absorbance value measured after incubation for $180 \mathrm{~min}$. Higher LPI value shows the higher antioxidant activity.

\subsubsection{Reducing Power}

The reducing power was determined following the method described in a previous study [33]. Various concentrations of each extract $(1 \mathrm{~mL}$ ) or BHT (with concentrations 25, 50, 100 and $250 \mathrm{ppm}$ in $\mathrm{MeOH})$ were mixed with $2.5 \mathrm{~mL}$ phosphate buffer $(0.2 \mathrm{M}, \mathrm{pH} 6.6)$ and $2.5 \mathrm{~mL}$ potassium ferricyanide $\left[\mathrm{K}_{3} \mathrm{Fe}(\mathrm{CN})_{6}\right](10 \mathrm{~g} / \mathrm{L})$. The obtained mixture was incubated at $50{ }^{\circ} \mathrm{C}$ for $30 \mathrm{~min}$, followed by adding $2.5 \mathrm{~mL}$ trichloroacetic acid $(100 \mathrm{~g} / \mathrm{L})$. The obtained mixture as centrifuged at $4000 \mathrm{rpm}$ for $10 \mathrm{~min}$. Finally, the upper layer $(0.5 \mathrm{~mL})$ was mixed with $0.5 \mathrm{ml}$ deionized water and $0.5 \mathrm{~mL} \mathrm{FeCl} 3(1 \mathrm{~g} / \mathrm{L})$. The absorbance was measured at $700 \mathrm{~nm}$; higher absorbance indicates higher reducing power. The absorbance ability of the reaction mixture is directly proportional to the reducing power.

\subsection{Antimicrobial Activity Test}

\subsubsection{Nutrient Agar Powder Preparation}

An amount of $4.5 \mathrm{~g}$ of agar powder and $6 \mathrm{~g}$ of LB broth (Lennox) were dissolved in $300 \mathrm{~mL}$ of distilled water and sterilized by autoclaving for $20 \mathrm{~min}$ in $121^{\circ} \mathrm{C}$. After that, about $20 \mathrm{~mL} \mathrm{LB}$ agar was 
poured into each sterilized petri plate $(86.5 \mathrm{~mm}$ diameter $\times 14.5 \mathrm{~mm}$ height). After cooling down to $55^{\circ} \mathrm{C}$, all agar petri dishes were stored at $4{ }^{\circ} \mathrm{C}$ in the dark for further experiments.

\subsubsection{LB Medium Preparation}

Two grams of LB broth were dissolved in $200 \mathrm{~mL}$ distilled water. The obtained mixture was sterilized for $20 \mathrm{~min}$ by autoclave at temperature $121^{\circ} \mathrm{C}$. The solution was cooled to $55^{\circ} \mathrm{C}$ and placed at temperature $4{ }^{\circ} \mathrm{C}$ in the dark for further experiments.

\subsubsection{Antimicrobial Test}

Antimicrobial activity of the sample extracts was evaluated using the disk diffusion agar method described by Fukuta et al. [18]. In this experiment, the LB broth medium was used to grow the bacteria for $24 \mathrm{~h}$ at $37^{\circ} \mathrm{C}$. The final population was standardized to be $1.26 \times 10^{8} \mathrm{CFU} / \mathrm{mL}$ (E. coli), $5.2 \times 10^{6} \mathrm{CFU} / \mathrm{mL}$ (K. pneumoniae), $1.8 \times 10^{6} \mathrm{CFU} / \mathrm{mL}$ (L. monocytogenes), $6.0 \times 10^{6} \mathrm{CFU} / \mathrm{mL}$ (B. subtilis), and $2.2 \times 10^{6} \mathrm{CFU} / \mathrm{mL}$ (P. mirabilis). An amount of $0.1 \mathrm{~mL}$ of the bacteria suspension was spreader evenly on each plate filled with the LB agar. After that, filter paper dishes (6 mm diameter) impregnated by $20 \mu \mathrm{L}$ of each sample extract (with a concentration $100 \mathrm{mg} / \mathrm{mL}$ in $\mathrm{MeOH}$ ) were laid on the surface of LB agar plates. After $24 \mathrm{~h}$ of incubation at $37^{\circ} \mathrm{C}$, the inhibition zone was measured. Ampicillin and streptomycin $(0.3 \mathrm{mg} /$ disc $)$ were used as standards in this assay.

2.6. Chemical Constituents Identification by Gas Chromatography-Mass Spectrometry (GC-MS), High Performance Liquid Chromatography (HPLC), and Electrospray Ionisation Mass Spectromety (EI-MS)

The chemical components of M1 to M26 were determined by using a GC-MS system. An aliquot of $1 \mu \mathrm{L}$ sample dissolved in methanol was injected into the GC-MS system (JMS-T100 GCV, JEOL Ltd., Tokyo, Japan). The column was DB-5MS and was $30 \mathrm{~m}$ in length, $0.25 \mathrm{~mm}$ internal diameter, and $0.25 \mu \mathrm{m}$ in thickness (Agilent Technologies, J \& W Scientific Products, Folsom, CA, USA.). Helium was chosen as the carrier gas, and the split ratio was 5:1. The method to operate GC oven temperatures was maintained, as the initial temperature was $50{ }^{\circ} \mathrm{C}$ without hold time, the programmed rate was $10^{\circ} \mathrm{C} \mathrm{min}^{-1}$ up to a final temperature of $300^{\circ} \mathrm{C}$ with $20 \mathrm{~min}$ of hold time. The injector and detector temperature were set at $300{ }^{\circ} \mathrm{C}$ and $320^{\circ} \mathrm{C}$, respectively. The mass range scanned from 29-800 amu. The control of the GC-MS system and the data peak processing were carried out using JEOL's GC-MS Mass Center System Version 2.65a. Compounds with peak areas $>0.3 \%$ in the GC-MS analysis were determined as principal substances.

The gradient liquid chromatographic system (model LC-10A series; Shimadzu, Tokyo, Japan) included two LC-10AD pumps controlled by a CMB-10A interface module, a model 7725i manual injector valve (Rheodyne) equipped with a $20 \mathrm{~mL}$ sample loop, and a multi-dimensional UV-VIS detector (model SPD-10A). Data were collected and analyzed using a class LC-10. The work station was equipped with an HP-DeskJet printer. The method involved the use of a Waters Spherisorb S10 ODS2 column $(250 \times 4.6 \mathrm{~mm}$, I.D., 10 microm $)$ and binary gradient mobile phase profile. The extraction efficiency, peak purity, and similarity were validated using a photo diode array detector, and a mobile phase consisting of $0.1 \%$ TFA in acetonitrile:water $(70: 30, v / v)$. The mobile phase was filtered through a $0.45 \mu \mathrm{m}$ Millipore filter and degassed by sonication for $30 \mathrm{~min}$. The flow rate was adjusted to $4 \mathrm{~mL} \mathrm{~min}{ }^{-1}$ with a run time of $50 \mathrm{~min}$. Injection volume was adjusted to $10 \mu \mathrm{L}$ and detection was made at $210 \mathrm{~nm}$. MA and MB were identified by HPLC and their peak areas were recorded. The presence of MA and MB were confirmed by an EI-MS system. MA: ESI ${ }^{+}: 315\left[\mathrm{M}+\mathrm{H}^{+}\right.$ $\left(\mathrm{C}_{20} \mathrm{H}_{27} \mathrm{O}_{3}\right)$; $\mathrm{ESI}^{-}: 313[\mathrm{M}-\mathrm{H}]^{-}\left(\mathrm{C}_{20} \mathrm{H}_{25} \mathrm{O}_{3}\right)$; HRMS 315.1959 [M + H] $]^{+}$(calc for $\mathrm{C}_{20} \mathrm{H}_{27} \mathrm{O}_{3}, 315.1960$ ). MB: ESI ${ }^{+}: 331\left[\mathrm{M}+\mathrm{H}^{+}\left(\mathrm{C}_{20} \mathrm{H}_{27} \mathrm{O}_{4}\right) ; \mathrm{ESI}^{-}: 329[\mathrm{M}-\mathrm{H}]^{-}\left(\mathrm{C}_{20} \mathrm{H}_{25} \mathrm{O}_{4}\right)\right.$; HRMS $330.1905\left[\mathrm{M}+\mathrm{H}^{+}\right.$ (calc for $\mathrm{C}_{20} \mathrm{H}_{27} \mathrm{O}_{4}, 315.1909$ ). 


\subsection{Statistical Analysis}

The data were analyzed by one-way ANOVA using the Minitab 16.0 software for Window. Upon significant differences, means were separated using Tukey's test at $p<0.05$ with three replications and expressed as means \pm standard deviation (SD) $(n=3)$.

\section{Results}

\subsection{Total Phenolic Content (TPC) and Total Flavonoid Content (TFC)}

The contents of total phenolics and flavonoids in EtOAc extracts prepared from rice husk varied from 63.8 to $5962.3 \mathrm{mg} \mathrm{GAE} / \mathrm{g} \mathrm{DW}$, and from 21.8 to $571.6 \mathrm{mg} \mathrm{RE} / \mathrm{g} \mathrm{DW}$, respectively (Table 2). The extraction of M7 (distilled water only, at $100{ }^{\circ} \mathrm{C}$ ) yielded the greatest TPC, followed by M6 (distilled water only at room temperature), whereas M7 was the most excellent in providing the maximum amount of TFC, followed by M17 (dried at $100{ }^{\circ} \mathrm{C}, 1 \mathrm{~h}$, combined with $\mathrm{MeOH} 30 \%$ ), and M6. The M17 method was potent in both TPC and TFC, and DPPH scavenging activity. The results suggest that the highest amount of phenolic and flavonoid was detected in M7.

\subsection{Antioxidant Activity by the DPPH Radical Scavenging Assay}

The DPPH radical scavenging activity of rice husk extracts are shown in Table 2 and is exhibited in $\mathrm{IC}_{50}$ value, of which, the smaller values indicate greater activity [34]. Table 2 showed that the DPPH radical scavenging activity in terms of $\mathrm{IC}_{50}$ values were varied among extractions. The extraction of M7 (distilled water only, at $100^{\circ} \mathrm{C}$ ) was found to yield the greatest TPC, followed by M6 (distilled water only at room temperature), whereas $\mathrm{M} 7$ was the most excellent in providing the maximum amount of TFC, followed by M17 (dried at $100{ }^{\circ} \mathrm{C}, 1 \mathrm{~h}$, combined with $\mathrm{MeOH} 30 \%$ ), and M6. The M17 method was potent in both TPC and TFC, and DPPH scavenging activity. The M20 (dried and then boiled at $100{ }^{\circ} \mathrm{C}$ for each $1 \mathrm{~h}$ ) resulted in the highest DPPH scavenging activity, followed by M3, M4, M6, and M17 (Table 2). However, the $\mathrm{IC}_{50}$ values of these extractions, including M20, were not statistically different.

\subsection{Antioxidant Activity by $\beta$-Carotene Bleaching Method}

The antioxidant activity and the percentage lipid peroxidation inhibition (\% LPI) results of the different methods are presented in Figure 1a,b. It was observed that the presence of antioxidants in different extractions prepared from rice husk reduced the oxidation of $\beta$-carotene (Figure 1a; Table S1). The LPI values varied from $67 \%$ to $86 \%$ (Figure $1 \mathrm{~b}$ ). Consequently, M10 (distilled water $\left.\left(100{ }^{\circ} \mathrm{C}, 1 \mathrm{~h}\right)+\mathrm{MeOH} 100 \%\right)$ shown the highest percent of LPI $(86 \%)$ meaning that it had the strongest antioxidant activity, following by M22 (dried $\left(100{ }^{\circ} \mathrm{C}, 2 \mathrm{~h}\right.$ ) and distilled water $\left.\left(100{ }^{\circ} \mathrm{C}, 2 \mathrm{~h}\right)+\mathrm{MeOH} 100 \%\right)(85 \%)$ (Figure $\left.1 \mathrm{~b}\right)$. Most of EtOAc extract inhibits $\beta$-carotene ranging from $76 \%$ to $82 \%$, contrarily, M7 (distilled water $\left(100{ }^{\circ} \mathrm{C}\right)(67 \%)$ was lower in antioxidant activity (Figure 1b; Table S1). However, there was not much difference among extracting solvents in the $\beta$-carotene bleaching method and lipid peroxidation inhibition.

\subsection{Reducing Power}

In the assay of the reducing power (Figure 2; Table S2), the yellow color of the test changes to green depending on the reducing power of the test specimen or capacity of each compound. The presence of substances (i.e., antioxidants) reduces $\mathrm{Fe}^{3+} /$ ferricyanide iron complex form. In this study, the reducing powers of rice husk extracts and BHT increased with the concentration of tested samples, of which M6 and M20 were the most potent, whereas no significant difference among other extractions was found. 
Table 2. Total phenolic content (TPC), total flavonoid content (TFC), and DPPH radical scavenging activity of rice husk in different extraction.

\begin{tabular}{|c|c|c|c|c|}
\hline Methods & Codes & TPC ( $\mu \mathrm{g}$ GAE/g) & TFC ( $\mu \mathrm{g}$ RE/g) & DPPH IC $50(\mathrm{ppm})$ \\
\hline $\mathrm{MeOH} 100 \%$ & M1 & $63.8 \pm 7.2 n$ & $25.8 \pm 2.0 \mathrm{jk}$ & $437.3 \pm 18.8 \mathrm{~b}$ \\
\hline $\mathrm{MeOH} \mathrm{70 \%}$ & M2 & $131.4 \pm 19.4 \mathrm{mn}$ & $34.7 \pm 3.9 \mathrm{jk}$ & $240.3 \pm 11.0 \mathrm{~d}$ \\
\hline $\mathrm{MeOH} \mathrm{50 \%}$ & M3 & $1128.0 \pm 80.2 \mathrm{e}$ & $177.9 \pm 8.5 \mathrm{~d}$ & $79.1 \pm 1.5 \mathrm{~h}$ \\
\hline $\mathrm{MeOH} \mathrm{30 \%}$ & M4 & $1894.9 \pm 129.1 \mathrm{~d}$ & $123.6 \pm 2.3 \mathrm{e}$ & $63.9 \pm 2.6 \mathrm{~h}$ \\
\hline $\mathrm{MeOH} \mathrm{10 \%}$ & M5 & $764.8 \pm 3.6 \mathrm{f}$ & $62.8 \pm 8.1 \mathrm{gh}$ & $310.7 \pm 22.6 c$ \\
\hline Distilled water (room temperature) & M6 & $5029.8 \pm 116.2 \mathrm{~b}$ & $229.2 \pm 11.1 \mathrm{c}$ & $56.7 \pm 1.1 \mathrm{~h}$ \\
\hline Distilled water $\left(100^{\circ} \mathrm{C}\right)$ & M7 & $5962.3 \pm 123.9 \mathrm{a}$ & $571.6 \pm 18.5 \mathrm{a}$ & $98.0 \pm 2.8 \mathrm{gh}$ \\
\hline Distilled water $\left(100^{\circ} \mathrm{C}, 30 \mathrm{~min}\right)+\mathrm{MeOH} 100 \%$ & M8 & $225.5 \pm 9.4 \mathrm{ijklmn}$ & $60.4 \pm 5.5 \mathrm{gh}$ & $200.3 \pm 7.4 \mathrm{de}$ \\
\hline Distilled water $\left(100^{\circ} \mathrm{C}, 30 \mathrm{~min}\right)+\mathrm{EtOAc} 100 \%$ & M9 & $180.2 \pm 21.0 \mathrm{klmn}$ & $38.3 \pm 5.8$ hijk & $247.7 \pm 22.6 \mathrm{~cd}$ \\
\hline Distilled water $\left(100{ }^{\circ} \mathrm{C}, 1 \mathrm{~h}\right)+\mathrm{MeOH} 100 \%$ & M10 & $211.7 \pm 10.0 \mathrm{jklmn}$ & $47.9 \pm 2.6$ ghij & $216.2 \pm 1.6 \mathrm{de}$ \\
\hline Distilled water $\left(100^{\circ} \mathrm{C}, 2 \mathrm{~h}\right)+\mathrm{MeOH} 100 \%$ & M11 & $316.9 \pm 17.0 \mathrm{hijkl}$ & $96.8 \pm 16.8 \mathrm{f}$ & $154.6 \pm 10.5 \mathrm{efg}$ \\
\hline Distilled water $\left(100{ }^{\circ} \mathrm{C}, 3 \mathrm{~h}\right)+\mathrm{MeOH} 100 \%$ & M12 & $254.3 \pm 25.8 \mathrm{ijklm}$ & $68.3 \pm 12.5 \mathrm{~g}$ & $220.9 \pm 41.4 \mathrm{de}$ \\
\hline Distilled water $\left(100{ }^{\circ} \mathrm{C}, 4 \mathrm{~h}\right)+\mathrm{MeOH} 100 \%$ & M13 & $158.3 \pm 19.4 \mathrm{lmn}$ & $28.1 \pm 3.1 \mathrm{jk}$ & $246.3 \pm 23.0 \mathrm{~cd}$ \\
\hline Dried $\left(100{ }^{\circ} \mathrm{C}, 1 \mathrm{~h}\right)+\mathrm{MeOH} 100 \%$ & M14 & $179.0 \pm 19.1 \mathrm{klmn}$ & $57.1 \pm 4.5 \mathrm{ghi}$ & $238.2 \pm 7.2 \mathrm{~d}$ \\
\hline Dried $\left(100^{\circ} \mathrm{C}, 1 \mathrm{~h}\right)+\mathrm{MeOH} 70 \%$ & M15 & $185.7 \pm 10.1 \mathrm{jklmn}$ & $35.3 \pm 1.6 \mathrm{jk}$ & $163.7 \pm 9.5 \mathrm{efg}$ \\
\hline Dried $\left(100{ }^{\circ} \mathrm{C}, 1 \mathrm{~h}\right)+\mathrm{MeOH} 50 \%$ & M16 & $391.9 \pm 46.8 \mathrm{hi}$ & $43.2 \pm 1.8$ hijk & $422.7 \pm 15.4 \mathrm{~b}$ \\
\hline Dried $\left(100{ }^{\circ} \mathrm{C}, 1 \mathrm{~h}\right)+\mathrm{MeOH} 30 \%$ & M17 & $3879.3 \pm 16.3 c$ & $308.4 \pm 17.5 \mathrm{~b}$ & $83.3 \pm 10.3 \mathrm{~h}$ \\
\hline Dried $\left(100^{\circ} \mathrm{C}, 1 \mathrm{~h}\right)+\mathrm{MeOH} 10 \%$ & M18 & $584.1 \pm 78.6 \mathrm{~g}$ & $109.9 \pm 4.6 \mathrm{ef}$ & $684.0 \pm 43.2 \mathrm{a}$ \\
\hline Dried $\left(100^{\circ} \mathrm{C}, 1 \mathrm{~h}\right)+$ distilled water (room temperature) & M19 & $392.4 \pm 88.8 \mathrm{hi}$ & $38.4 \pm 1.4$ hijk & $214.5 \pm 2.7 \mathrm{de}$ \\
\hline Dried $\left(100^{\circ} \mathrm{C}, 1 \mathrm{~h}\right)+$ distilled water $\left(100^{\circ} \mathrm{C}\right)$ & M20 & $353.9 \pm 23.0$ hij & $21.8 \pm 0.9 \mathrm{k}$ & $54.7 \pm 2.5 \mathrm{~h}$ \\
\hline Dried $\left(100^{\circ} \mathrm{C}, 1 \mathrm{~h}\right)$, distilled water $\left(100^{\circ} \mathrm{C}, 1 \mathrm{~h}\right)+\mathrm{MeOH} 100 \%$ & M21 & $266.2 \pm 9.3$ hijklm & $46.7 \pm 3.7$ ghijk & $203.6 \pm 8.7 \mathrm{de}$ \\
\hline Dried $\left(100^{\circ} \mathrm{C}, 2 \mathrm{~h}\right)$, distilled water $\left(100^{\circ} \mathrm{C}, 2 \mathrm{~h}\right)+\mathrm{MeOH} 100 \%$ & M22 & $341.7 \pm 13.5$ hijk & $101.7 \pm 6.2 \mathrm{ef}$ & $183.5 \pm 73.5 \mathrm{def}$ \\
\hline Dried $\left(100^{\circ} \mathrm{C}, 3 \mathrm{~h}\right)$, distilled water $\left(100^{\circ} \mathrm{C}, 3 \mathrm{~h}\right)+\mathrm{MeOH} 100 \%$ & M23 & $239.3 \pm 22.8 \mathrm{ijklm}$ & $56.3 \pm 3.8$ ghi & $189.9 \pm 22.6 \mathrm{de}$ \\
\hline Dried $\left(100^{\circ} \mathrm{C}, 4 \mathrm{~h}\right)$, distilled water $\left(100^{\circ} \mathrm{C}, 4 \mathrm{~h}\right)+\mathrm{MeOH} 100 \%$ & M24 & $175.7 \pm 18.5 \mathrm{klmn}$ & $29.6 \pm 1.5 \mathrm{jk}$ & $251.0 \pm 6.7 \mathrm{~cd}$ \\
\hline Distilled water $\left(100^{\circ} \mathrm{C}, 120 \mathrm{kPa}\right)+\mathrm{MeOH} 100 \%$ & M25 & $333.3 \pm 20.4$ hijk & $62.4 \pm 3.9 \mathrm{gh}$ & $167.1 \pm 4.9 \mathrm{efg}$ \\
\hline \multirow[t]{2}{*}{ Dried $\left(100{ }^{\circ} \mathrm{C}, 120 \mathrm{kPa}\right)+\mathrm{MeOH} 100 \%$} & M26 & $430.0 \pm 27.0 \mathrm{gh}$ & $93.7 \pm 5.7 \mathrm{f}$ & $113.7 \pm 20.8 \mathrm{fgh}$ \\
\hline & BHT & $e^{-}$ & - & $9.3 \pm 1.1 \mathrm{i}$ \\
\hline
\end{tabular}

Values represent means $\pm \mathrm{SD}$ (standard deviation). Values with similar letters in each column are not significantly different $(p<0.05)(n=3)$. -: measurement was not conducted; BHT: Butylated hydroxytoluene; TPC: total phenolic content; TFC: total flavonoid content. 


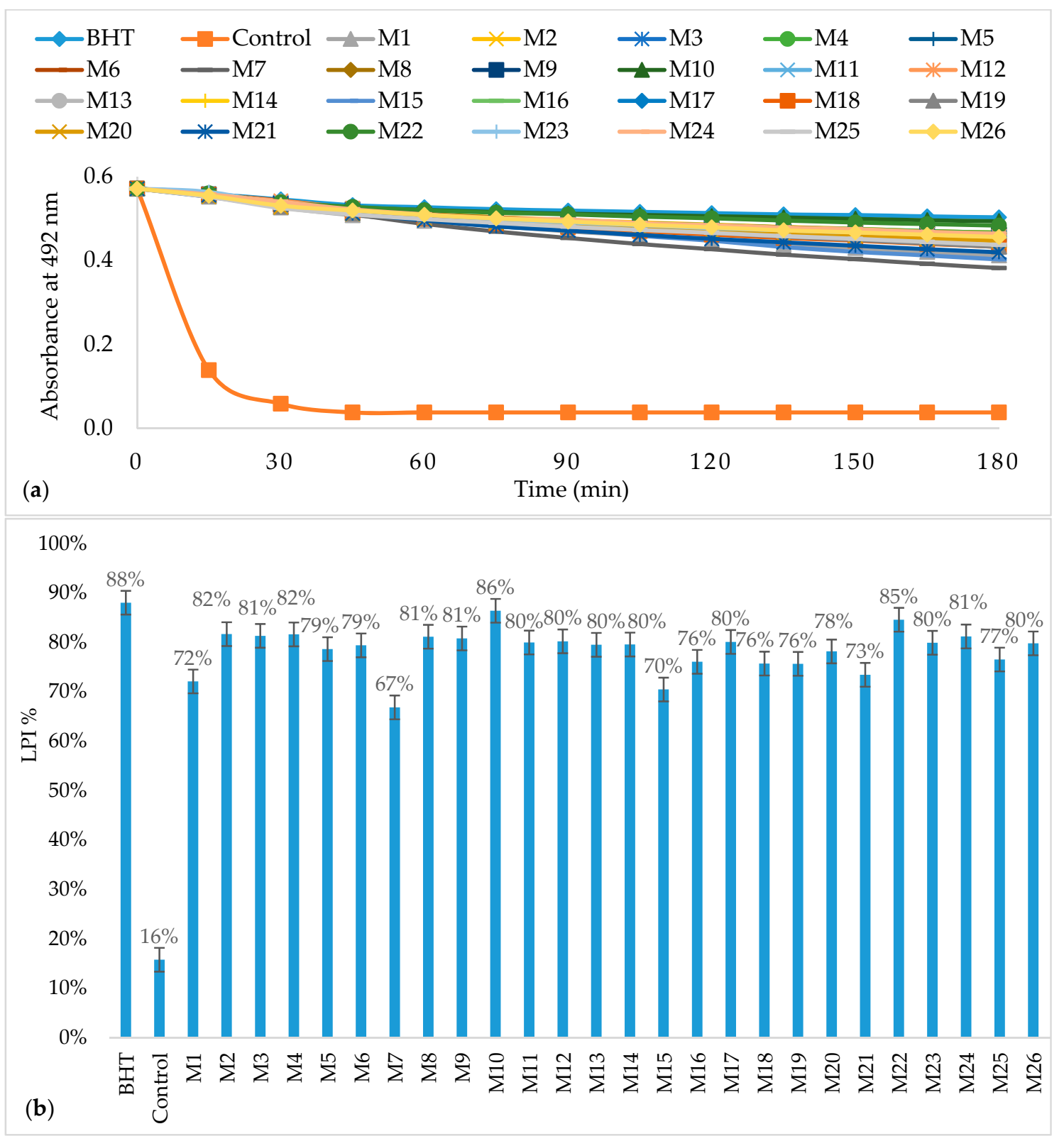

Figure 1. Antioxidant activities, measured by $\beta$-carotene bleaching method (a) and their lipid peroxidation inhibition (\%LPI) (b); Control (MeOH); BHT: butylated hydroxytoluene.

\subsection{Antimicrobial Activity}

The antimicrobial activities of different extractions on growth of five bacteria including E. coli, K. pneumoiae, L. monocytogenes, B. subtilis, and P. mirabilis are shown in Table 3. It was found that the antimicrobial activity varied among bacteria and extractions. As compared to the standards including ampicillin and streptomycin, the inhibitory level can be ranked as follows: E. coli $>$ B. subtilis > K. pneumoniae and L. monocytogenes $>$ P. mirabilis. Among the individual bacteria, the strongest antimicrobial activity on B. subtilis was observed in M3-M5, M9, M13, M15, M17-M18, and M24 which showed the suppressive level was similar to that of streptomycin. In the case of L. monocytogenes, M19-M20, M5, and M18 were the extractions with the strongest inhibition. In K. pneunomiae, M4 and M18 were the best candidates to inhibit growth of the bacteria, but they were statistically similar to M2-M3, M10, M12-M13, M17, M19, M23-M24, and M26 (Table 3). In E. coli, while the M21 was shown 
to be the least effective, the other extractions showed similar antimicrobial activity. In P. mirabilis, extractions M9, M11-13, M18, M20, and M22 exerted maximum inhibition.

Compared among extractions, M18 was the most potent and showed the strongest inhibition against emergence of all studied bacteria, followed by M3, M4, M21, and M13 (Table 3). M1, M22, M23, M25 showed the least effectiveness as they showed strong antimicrobial activity with only one bacteria species, whereas the activity of the M14 remained unknown, as it did not show strong inhibition on L. monocytogenes, B. subtilis, and P. mirabilis, whilst the examination on E. coli and K. pneumoniae was not conducted (Table 3).

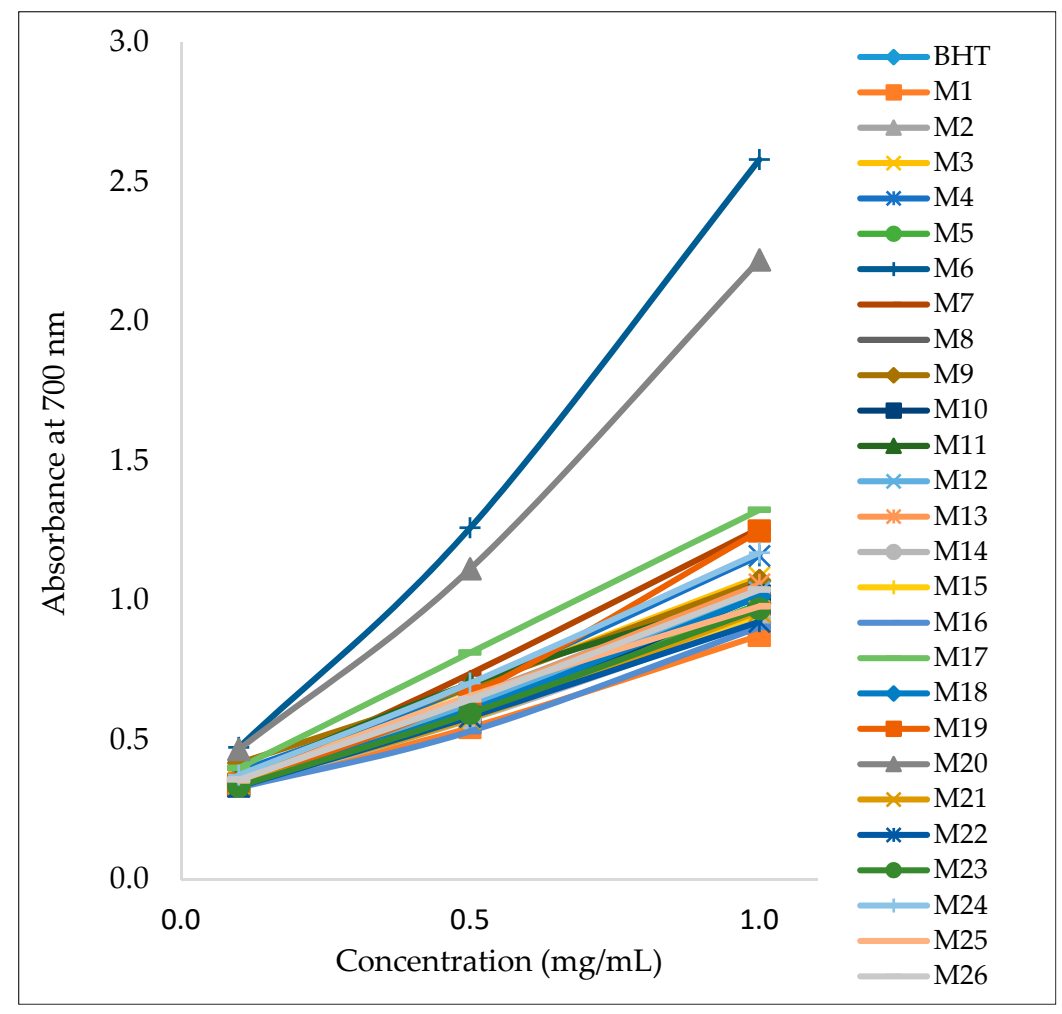

Figure 2. Reducing power activity of rice husk in different extraction and standard antioxidant. BHT: butylated hydroxytoluene

\subsection{Identification Compound from each Ethyl Acetate Extractions}

By GC-MS, major compounds in rice husk relevant to different extracts were identified and showed in Table 4. They included cis-11-octadecenoic acid methyl ester, momilactone A, momilactone B, n-hexadecanoic acid methyl ester, 4-((1E)-3-hydroxy-1-propenyl)-2-methoxyphenol, methyl (2E)-3-(4-hydroxyphenyl)-2-propenoate, trans-p-coumaric acid, 3-hydroxy-4-methoxybenzoic acid, L-lactic acid, butanoic acid, catechol, hexanoic acid, 4-hydroxybenzenepropanoic acid, phenol, and dihydrobenzofuran (Table 4). These chemicals belonged to momilactones, phenolic acids, phenols, and long-chain fatty acids. It was found that the presence of chemicals varied among extracting protocols, of which cis-11-octadecenoic acid methyl ester, 4-((1E)-3-hydroxy-1-propenyl)2-methoxyphenol, and trans- $p$-coumaric acid accounted for greater peak areas as compared to other putative constituents (Table 4). The peak areas of momilactones A and B (MA and MB, respectively) were lesser than these compounds. However, $\mathrm{MA}$ and $\mathrm{MB}$ were not detected in the extracts with only distilled water or $\mathrm{MeOH} \leq 50 \%$ at any temperature (M3-M5; M6-M7; M16-M20) (Tables 1 and 3). cis-11-Octadecenoic acid methyl ester was found in M1, M2, M11, M12, M15, M18, M22, M23, whilst 4-((1E)-3-hydroxy-1-propenyl)-2-methoxyphenol and trans-p-coumaric acid were detected in M3, M4, M8-M14, M16, M17, M21, and M24-M26 (Table 4). 
Table 3. Antimicrobial activity of different extraction on five bacteria.

\begin{tabular}{|c|c|c|c|c|c|c|}
\hline \multirow{2}{*}{ Methods } & \multirow{2}{*}{ Codes } & \multicolumn{5}{|c|}{ Zone of Inhibition (mm) } \\
\hline & & E. coli & K. pneumoniae & L. monocytogenes & B. subtilis & P. mirabilis \\
\hline $\mathrm{MeOH} 100 \%$ & M1 & $9.7 \pm 1.5 \mathrm{cdef}$ & $7.7 \pm 1.2 \mathrm{~cd}$ & $7.3 \pm 0.6 \mathrm{~h}$ & $6.3 \pm 0.6 \mathrm{~h}$ & - \\
\hline $\mathrm{MeOH} 70 \%$ & M2 & $10.3 \pm 0.6 \mathrm{cdef}$ & $8.3 \pm 1.5 \mathrm{~cd}$ & $9.3 \pm 0.6 \mathrm{fgh}$ & $8.3 \pm 0.6$ defgh & - \\
\hline $\mathrm{MeOH} 50 \%$ & M3 & $9.0 \pm 1.0 \mathrm{cdef}$ & $9.3 \pm 1.2 \mathrm{~cd}$ & $12.3 \pm 7.6$ cde & $10.7 \pm 0.6$ bcde & $7.3 \pm 1.6 \mathrm{fg}$ \\
\hline $\mathrm{MeOH} 30 \%$ & M4 & $11.7 \pm 0.6 \mathrm{~cd}$ & $10.3 \pm 0.6 \mathrm{c}$ & $12.3 \pm 7.6$ cde & $9.7 \pm 0.6$ bcdef & $7.3 \pm 0.6 \mathrm{fg}$ \\
\hline $\mathrm{MeOH} 10 \%$ & M5 & $11.0 \pm 1.7 \mathrm{~cd}$ & $6.3 \pm 0.6 \mathrm{~d}$ & $13.7 \pm 7.6 \mathrm{c}$ & $10.0 \pm 1.0 \mathrm{bcde}$ & $7.3 \pm 1.6 \mathrm{fg}$ \\
\hline Distilled water (room temperature) & M6 & $10.0 \pm 1.7 \mathrm{cdef}$ & $6.3 \pm 0.6 \mathrm{~d}$ & $9.7 \pm 7.6 \mathrm{efgh}$ & $9.0 \pm 1.0$ cdefg & $7.3 \pm 1.6 \mathrm{fg}$ \\
\hline Distilled water $\left(100^{\circ} \mathrm{C}\right)$ & M7 & - & - & - & - & $7.3 \pm 0.6 \mathrm{fg}$ \\
\hline Distilled water $\left(100{ }^{\circ} \mathrm{C}, 30 \mathrm{~min}\right)+\mathrm{MeOH} 100 \%$ & M8 & $8.3 \pm 1.5 \mathrm{cdef}$ & $6.3 \pm 0.6 \mathrm{~d}$ & $9.3 \pm 0.6 \mathrm{fgh}$ & $8.3 \pm 0.6$ defgh & - \\
\hline Distilled water $\left(100^{\circ} \mathrm{C}, 30 \mathrm{~min}\right)+$ EtOAc $100 \%$ & M9 & $12.0 \pm 1.7 \mathrm{c}$ & - & $8.3 \pm 9.6 \mathrm{gh}$ & $9.7 \pm 0.6$ bcdef & $10.0 \pm 1.0 \mathrm{cdef}$ \\
\hline Distilled water $\left(100^{\circ} \mathrm{C}, 1 \mathrm{~h}\right)+\mathrm{MeOH} 100 \%$ & M10 & $9.3 \pm 1.5 \mathrm{cdef}$ & $6.7 \pm 1.2 \mathrm{~cd}$ & $8.7 \pm 7.5 \mathrm{fgh}$ & $8.3 \pm 0.6$ defgh & $7.3 \pm 1.6 \mathrm{fg}$ \\
\hline Distilled water $\left(100^{\circ} \mathrm{C}, 2 \mathrm{~h}\right)+\mathrm{MeOH} 100 \%$ & M11 & $12.3 \pm 2.1 \mathrm{c}$ & - & $7.3 \pm 0.6 \mathrm{~h}$ & $6.7 \pm 1.2 \mathrm{gh}$ & $9.7 \pm 2.6 \mathrm{cdef}$ \\
\hline Distilled water $\left(100^{\circ} \mathrm{C}, 3 \mathrm{~h}\right)+\mathrm{MeOH} 100 \%$ & M12 & $7.7 \pm 2.1 \mathrm{def}$ & $7.3 \pm 0.6 \mathrm{~cd}$ & $10.0 \pm 1.0$ defgh & $9.3 \pm 0.6$ cdef & $10.7 \pm 2.6 \mathrm{cde}$ \\
\hline Distilled water $\left(100^{\circ} \mathrm{C}, 4 \mathrm{~h}\right)+\mathrm{MeOH} 100 \%$ & M13 & $10.3 \pm 0.6$ cdef & $8.3 \pm 1.2 \mathrm{~cd}$ & $10.3 \pm 9.6 \mathrm{defg}$ & $10.3 \pm 0.6$ bcde & $9.7 \pm 0.2 \mathrm{cdef}$ \\
\hline Dried $\left(100{ }^{\circ} \mathrm{C}, 1 \mathrm{~h}\right)+\mathrm{MeOH} 100 \%$ & M14 & - & - & $7.3 \pm 0.6 \mathrm{~h}$ & $6.3 \pm 0.6 \mathrm{~h}$ & $8.7 \pm 0.5 \mathrm{efg}$ \\
\hline Dried $\left(100^{\circ} \mathrm{C}, 1 \mathrm{~h}\right)+\mathrm{MeOH} 70 \%$ & M15 & $9.0 \pm 0.0 \mathrm{cdef}$ & - & $8.3 \pm 0.6 \mathrm{gh}$ & $10.7 \pm 0.6$ bcde & - \\
\hline Dried $\left(100{ }^{\circ} \mathrm{C}, 1 \mathrm{~h}\right)+\mathrm{MeOH} 50 \%$ & M16 & $10.0 \pm 1.7 \mathrm{cdef}$ & - & $9.7 \pm 6.6$ efgh & $7.3 \pm 0.6 \mathrm{fhg}$ & $6.3 \pm 1.6 \mathrm{~g}$ \\
\hline Dried $\left(100{ }^{\circ} \mathrm{C}, 1 \mathrm{~h}\right)+\mathrm{MeOH} 30 \%$ & M17 & $10.7 \pm 1.5 \mathrm{cde}$ & $7.0 \pm 1.0 \mathrm{~cd}$ & $11.3 \pm 6.6$ cdef & $10.3 \pm 0.6$ bcde & $6.3 \pm 1.6 \mathrm{~g}$ \\
\hline Dried $\left(100{ }^{\circ} \mathrm{C}, 1 \mathrm{~h}\right)+\mathrm{MeOH} 10 \%$ & M18 & $9.3 \pm 1.5 \mathrm{cdef}$ & $10.3 \pm 1.5 \mathrm{c}$ & $13.7 \pm 1.6 \mathrm{c}$ & $11.3 \pm 0.6 \mathrm{bc}$ & $11.7 \pm 1.6 \mathrm{cde}$ \\
\hline Dried $\left(100^{\circ} \mathrm{C}, 1 \mathrm{~h}\right)+$ distilled water (room temperature) & M19 & $10.0 \pm 1.0 \mathrm{cdef}$ & $7.3 \pm 1.5 \mathrm{~cd}$ & $16.7 \pm 8.6 \mathrm{~b}$ & - & $8.3 \pm 1.6 \mathrm{efg}$ \\
\hline Dried $\left(100^{\circ} \mathrm{C}, 1 \mathrm{~h}\right)+$ distilled water $\left(100^{\circ} \mathrm{C}\right)$ & M20 & $9.3 \pm 1.2 \mathrm{cdef}$ & $6.3 \pm 0.6 \mathrm{~d}$ & $17.7 \pm 0.6 \mathrm{~b}$ & $8.7 \pm 1.2$ defgh & $10.7 \pm 1.6 \mathrm{cde}$ \\
\hline Dried $\left(100^{\circ} \mathrm{C}, 1 \mathrm{~h}\right)$, distilled water $\left(100^{\circ} \mathrm{C}, 1 \mathrm{~h}\right)+\mathrm{MeOH} 100 \%$ & M21 & $6.3 \pm 0.6 \mathrm{f}$ & $6.3 \pm 0.6 \mathrm{~d}$ & $12.7 \pm 8.6 \mathrm{~cd}$ & $7.3 \pm 0.6 \mathrm{fhg}$ & $8.3 \pm 0.6 \mathrm{efg}$ \\
\hline Dried $\left(100^{\circ} \mathrm{C}, 2 \mathrm{~h}\right)$, distilled water $\left(100^{\circ} \mathrm{C}, 2 \mathrm{~h}\right)+\mathrm{MeOH} 100 \%$ & M22 & $9.7 \pm 0.6 \mathrm{cdef}$ & - & $8.7 \pm 1.6 \mathrm{fgh}$ & - & $12.3 \pm 0.5 \mathrm{c}$ \\
\hline Dried $\left(100^{\circ} \mathrm{C}, 3 \mathrm{~h}\right)$, distilled water $\left(100^{\circ} \mathrm{C}, 3 \mathrm{~h}\right)+\mathrm{MeOH} 100 \%$ & M23 & $6.7 \pm 1.2 \mathrm{ef}$ & $8.3 \pm 0.6 \mathrm{~cd}$ & $8.3 \pm 8.6 \mathrm{gh}$ & $7.7 \pm 0.6$ efgh & $9.0 \pm 1.0 \mathrm{defg}$ \\
\hline Dried $\left(100^{\circ} \mathrm{C}, 4 \mathrm{~h}\right)$, distilled water $\left(100{ }^{\circ} \mathrm{C}, 4 \mathrm{~h}\right)+\mathrm{MeOH} 100 \%$ & M24 & $8.3 \pm 0.6 \mathrm{cdef}$ & $10.0 \pm 1.0 \mathrm{~cd}$ & $10.3 \pm 9.6$ defg & $9.7 \pm 0.6$ bcdef & $8.7 \pm 0.6 \mathrm{efg}$ \\
\hline Distilled water $\left(100^{\circ} \mathrm{C}, 120 \mathrm{kPa}\right)+\mathrm{MeOH} 100 \%$ & M25 & $9.0 \pm 1.7 \mathrm{cdef}$ & - & $7.3 \pm 9.6 \mathrm{~h}$ & $6.3 \pm 0.6 \mathrm{~h}$ & $9.0 \pm 1.0$ defg \\
\hline Dried $\left(100{ }^{\circ} \mathrm{C}, 120 \mathrm{kPa}\right)+\mathrm{MeOH} 100 \%$ & M26 & $7.7 \pm 0.6 \mathrm{def}$ & $9.3 \pm 1.2 \mathrm{~cd}$ & $8.3 \pm 0.6 \mathrm{gh}$ & $6.3 \pm 0.6 \mathrm{~h}$ & - \\
\hline Methanol & $\mathrm{MeOH}$ & - & - & - & - & - \\
\hline Ampicillin & Amp & $34.0 \pm 1.0 \mathrm{a}$ & $44.3 \pm 3.2 \mathrm{a}$ & $24.7 \pm 3.1 \mathrm{a}$ & $17.3 \pm 1.5 \mathrm{a}$ & $43.3 \pm 1.5 \mathrm{a}$ \\
\hline Streptomycin & Str & $19.0 \pm 1.0 \mathrm{~b}$ & $15.3 \pm 0.6 \mathrm{~b}$ & $18.0 \pm 1.7 \mathrm{~b}$ & $12.0 \pm 1.0 \mathrm{~b}$ & $29.3 \pm 1.5 b$ \\
\hline
\end{tabular}

Values represent means \pm SD (standard deviation). Values with similar letters in a column are not significantly different $(p<0.05)$; -: not measured; BHT: butylated hydroxytoluene. 
Table 4. Principal compounds identified in rice husk.

\begin{tabular}{|c|c|c|c|c|}
\hline Methods & Codes & Major Constituents & Retention Times (min) & Peak Area (\%) \\
\hline $\mathrm{MeOH} 100 \%$ & M1 & OA, MA, MB, HaM & $18.42,18.70,15.04,16.73$ & $19.26,0.33,0.98,1.97$ \\
\hline $\mathrm{MeOH} \mathrm{70 \%}$ & M2 & $\mathrm{OA}, \mathrm{MA}, \mathrm{MB}, \mathrm{HaM}$ & $18.42,18.70,15.04,16.73$ & $22.04,0.53,1.05,1.85$ \\
\hline $\mathrm{MeOH} 50 \%$ & M3 & $\mathrm{HM}, \mathrm{PM}, p \mathrm{C}$ & $14.78,14.90,15.25$ & $27.76,18.41,9.45$ \\
\hline $\mathrm{MeOH} 30 \%$ & M4 & $\mathrm{HM}, \mathrm{HmA}, p \mathrm{C}$ & $14.78,12.81,15.25$ & $28.22,9.95,31.24$ \\
\hline $\mathrm{MeOH} 10 \%$ & M5 & LA, HmA, BA & $3.63,12.81,3.00$ & $45.68,12.82,7.28$ \\
\hline Distilled water (room temperature) & M6 & $\mathrm{BA}, \mathrm{Ca}, \mathrm{HA}$ & $3.00,7.85,5.01$ & $19.54,9.53,15.08$ \\
\hline Distilled water $\left(100^{\circ} \mathrm{C}\right)$ & M7 & $\mathrm{BeA}, \mathrm{P}, \mathrm{Ca}$ & $13.56,4.74,7.85$ & $21.22,10.32,19.04$ \\
\hline Distilled water $\left(100{ }^{\circ} \mathrm{C}, 30 \mathrm{~min}\right)+\mathrm{MeOH} 100 \%$ & M8 & $\mathrm{HM}, p \mathrm{C}, \mathrm{MA}, \mathrm{MB}$ & $14.78,15.25,18.70,15.04$ & $21.49,12.09,1.21,3.03$ \\
\hline Distilled water $\left(100^{\circ} \mathrm{C}, 30 \mathrm{~min}\right)+\mathrm{EtOAc} 100 \%$ & M9 & $\mathrm{HM}, p \mathrm{C}, \mathrm{MA}, \mathrm{MB}$ & $14.78,15.25,18.70,15.04$ & $24.71,19.01,1.12,2.18$ \\
\hline Distilled water $\left(100{ }^{\circ} \mathrm{C}, 1 \mathrm{~h}\right)+\mathrm{MeOH} 100 \%$ & M10 & $\mathrm{HM}, p \mathrm{C}, \mathrm{MA}, \mathrm{MB}$ & $14.78,15.25,18.70,15.04$ & $28.28,8.43,2.36,0.71$ \\
\hline Distilled water $\left(100^{\circ} \mathrm{C}, 2 \mathrm{~h}\right)+\mathrm{MeOH} 100 \%$ & M11 & $\mathrm{HM}, \mathrm{OA}, \mathrm{MA}, \mathrm{MB}$ & $14.78,18.42,18.70,15.04$ & $20.26,18.78,3.71,7.33$ \\
\hline Distilled water $\left(100^{\circ} \mathrm{C}, 3 \mathrm{~h}\right)+\mathrm{MeOH} 100 \%$ & M12 & $\mathrm{HM}, \mathrm{OA}, \mathrm{MA}, \mathrm{MB}$ & $14.78,18.42,18.70,15.04$ & $14.06,14.07,0.55,1.53$ \\
\hline Distilled water $\left(100^{\circ} \mathrm{C}, 4 \mathrm{~h}\right)+\mathrm{MeOH} 100 \%$ & M13 & $\mathrm{HM}, p \mathrm{C}, \mathrm{MA}, \mathrm{MB}$ & $14.78,15.25,18.70,15.04$ & $33.78,31.49,1.55,3.12$ \\
\hline Dried $\left(100^{\circ} \mathrm{C}, 1 \mathrm{~h}\right)+\mathrm{MeOH} 100 \%$ & M14 & $\mathrm{HM}, p \mathrm{C}, \mathrm{MA}, \mathrm{MB}$ & $14.78,15.25,18.70,15.04$ & $26.88,8.26,4.11,8.09$ \\
\hline Dried $\left(100{ }^{\circ} \mathrm{C}, 1 \mathrm{~h}\right)+\mathrm{MeOH} 70 \%$ & M15 & HaM, OA, MA, MB & $16.73,18.42,18.70,15.04$ & $19.54,42.11,1.82,3.16$ \\
\hline Dried $\left(100{ }^{\circ} \mathrm{C}, 1 \mathrm{~h}\right)+\mathrm{MeOH} 50 \%$ & M16 & $\mathrm{HM}, p \mathrm{C}$ & $14.78,15.25$ & $37.53,7.71$ \\
\hline Dried $\left(100{ }^{\circ} \mathrm{C}, 1 \mathrm{~h}\right)+\mathrm{MeOH} 30 \%$ & M17 & $\mathrm{Be}, \mathrm{HM}, p \mathrm{C}$ & $8.21,14.78,15.25$ & $15.17,20.49,17.55$ \\
\hline Dried $\left(100{ }^{\circ} \mathrm{C}, 1 \mathrm{~h}\right)+\mathrm{MeOH} 10 \%$ & M18 & OA, HaM & $18.42,16.73$ & $16.93,8.99$ \\
\hline Dried $\left(100^{\circ} \mathrm{C}, 1 \mathrm{~h}\right)+$ distilled water (room temperature) & M19 & BA, P & $3.00,4.74$ & $54.35,16.22$ \\
\hline Dried $\left(100^{\circ} \mathrm{C}, 1 \mathrm{~h}\right)+$ distilled water $\left(100^{\circ} \mathrm{C}\right)$ & M20 & $\mathrm{BA}, \mathrm{BeA}$ & $3.00,13.56$ & $54.8,8.01$ \\
\hline Dried $\left(100^{\circ} \mathrm{C}, 1 \mathrm{~h}\right)$, distilled water $\left(100^{\circ} \mathrm{C}, 1 \mathrm{~h}\right)+\mathrm{MeOH} 100 \%$ & M21 & $\mathrm{HM}, p \mathrm{C}, \mathrm{MA}, \mathrm{MB}$ & $14.78,15.25,18.70,15.04$ & $50.85,24.01,1.12,1.07$ \\
\hline Dried $\left(100^{\circ} \mathrm{C}, 2 \mathrm{~h}\right)$, distilled water $\left(100^{\circ} \mathrm{C}, 2 \mathrm{~h}\right)+\mathrm{MeOH} 100 \%$ & M22 & $\mathrm{HM}, \mathrm{OA}, \mathrm{MA}, \mathrm{MB}$ & $14.78,18.42,18.70,15.04$ & $21.82,21.96,1.26,2.88$ \\
\hline Dried $\left(100{ }^{\circ} \mathrm{C}, 3 \mathrm{~h}\right)$, distilled water $\left(100{ }^{\circ} \mathrm{C}, 3 \mathrm{~h}\right)+\mathrm{MeOH} 100 \%$ & M23 & HaM, OA, MA, MB & $16.73,18.42,18.70,15.04$ & $12.13,17.72,2.21,4.48$ \\
\hline Dried $\left(100{ }^{\circ} \mathrm{C}, 4 \mathrm{~h}\right)$, distilled water $\left(100^{\circ} \mathrm{C}, 4 \mathrm{~h}\right)+\mathrm{MeOH} 100 \%$ & M24 & $\mathrm{HM}, p \mathrm{C}, \mathrm{MA}, \mathrm{MB}$ & $14.78,15.25,18.70,15.04$ & $23.05,20.13,0.98,3.01$ \\
\hline Distilled water $\left(100^{\circ} \mathrm{C}, 120 \mathrm{kPa}\right)+\mathrm{MeOH} 100 \%$ & M25 & $\mathrm{HM}, p \mathrm{C}, \mathrm{MA}, \mathrm{MB}$ & $14.78,15.25,18.70,15.04$ & $43.85,29.00,2.02,3.05$ \\
\hline Dried $\left(100^{\circ} \mathrm{C}, 120 \mathrm{kPa}\right)+\mathrm{MeOH} 100 \%$ & M26 & $\mathrm{HM}, p \mathrm{C}, \mathrm{MA}, \mathrm{MB}$ & $14.78,15.25,18.70,15.04$ & $52.46,15.75,0.22,3.08$ \\
\hline
\end{tabular}




\section{Discussion}

Rice husk, an agricultural waste, is abundantly available in rice producing countries. It is also of high calorific value, making it a good source of renewable energy [35]. Except for important sustainable energy value, the search for phytochemicals which may be exploited for herbal drug preparations on rice husk has been conducted sporadically [36,37]. Momilactones A (MA) and B (MB) were isolated from rice husk and found to be correlated to the drought and salinity tolerance capacities [19]; these compounds concentrated on plan growth, pathogen, and antioxidant capacity [18], and cytotoxic and antitumor activity [38]. Both MA and MB further were found from many other rice cultivars $[38,39]$. However, this study is the initial step to observe that rice husk, especially the EtOAc extract, contains rich antioxidants that should be exploited. M7 (distilled water only, at $100{ }^{\circ} \mathrm{C}$ ) was found to yield the greatest TPC and TFC. M6 (distilled water only at room temperature) and M20 (dried and then boiled at $100^{\circ} \mathrm{C}$ for each $1 \mathrm{~h}$ ) were shown to be strongest in antioxidant capacity. M18, which was the most potent, showed a strong inhibition against emergence of all studied bacteria (temperature $100{ }^{\circ} \mathrm{C}+10 \% \mathrm{MeOH}$ ) (Tables 1 and 3).

Annual worldwide production of rice husk is about 120 million tons, of which the amounts from China, India, Indonesia, Bangladesh, Vietnam, Thailand, Philippines, and Japan were 35.3, $25.5,10.5,7.6,6.9,5.2,4.6,2.7$, and 2.2 million tons, respectively [1]. Remarkable production of rice husk outside of Asian countries took place in Brazil (2.3 million tons) [1]. This causes serious problems for disposal and results in environmental problem [40]. Because rice husk has 15-20\% silica, cellulose $(35 \%)$, hemicellulose $(25 \%)$, ash $(17 \%)$, and only $2 \%$ protein, it is difficult to exploit it as a valuable product $[3,4]$. The use of chemicals in pre-treatment $\mathrm{H}_{2} \mathrm{SO}_{4}[2,8], \mathrm{ZnCl}_{2}$ and $\mathrm{H}_{3} \mathrm{PO}_{4}[9,10]$, and $\mathrm{KOH}$ [11] and $\mathrm{NaOH}$ [12], for decomposing rice husk is convenient, but these solvents are toxic for humans and the environment. Thus, the use of temperature, pressure, $\mathrm{EtOAc}, \mathrm{MeOH}$, and water in this study are more ecofriendly. At an industrial scale, $\mathrm{MeOH}$ could be replaced by $\mathrm{C}_{2} \mathrm{H}_{5} \mathrm{OH}$ which is much safer for humans. The optimization of antioxidant and antimicrobial activities needs only a minimum of $10 \% \mathrm{MeOH}$ (Tables 1-3; Figures 1 and 2), therefore it turns to be safe as this amount can be easily evaporated during processing.

This study revealed that major constituents in rice husk included momilactones A and B, phenols, phenolic acids, and long-chain fatty acids, although their presences varied among extracting protocols (Table 4). There were 3 constituents, including cis-11-octadecenoic acid methyl ester, 4-((1E)-3-hydroxy-1-propenyl)-2-methoxyphenol, and trans-p-coumaric acid, which obtained the maximum peak areas as compared to other compounds. MA and MB were also the major chemicals but appeared with lesser peak areas and they were not detected in the extracts with either solely distilled water or $\mathrm{MeOH} \leq 50 \%$ at any temperature (Tables 1 and 3). Among them, MA and MB and trans-p-coumaric acid have been known as bioactive compounds, thus their existence may help to increase the value of rice husk. In this study, because many identified can neither successfully be purified nor purchased, the peak areas were used to compare the efficacy of different extracting protocols. The use of standards of these identified constituents for quantification will help determine with more accuracy the quantities of chemicals obtained in rice husk, that need further elaboration.

Findings of this study suggest that the quantity of paddy rice by-product's waste can be reduced when rice husk can be exploited for medicinal and pharmaceutical purposes, as it is revealed to possess rich and safe antioxidants, and antimicrobials. The use of temperature, extracting solvents, and pressure, as shown in this study, to optimize the antioxidant and antimicrobial capacities is useful to apply at an industrial scale. The search for novel bioactive compounds in rice husk will also help to foster the valuable use of the rice by-product.

\section{Conclusions}

This study indicated that the extracts prepared from rice husk contained potent amounts of phenolic and flavonoid contents. Rice husk also showed promising antioxidant and antimicrobial 
activity. The use of temperature at $100{ }^{\circ} \mathrm{C}$ for $>2 \mathrm{~h}$, combined with either EtOAc or $10 \% \mathrm{MeOH}$ can optimize the chemical components and antioxidant and antimicrobial capacities of rice husk.

Supplementary Materials: The following are available online at http:/ /www.mdpi.com/2071-1050/10/5/1356/s1, Table S1: $\beta$-carotene bleaching inhibiting activity. Table S2: EtOAc extracts, and BHT measured by reducing power method.

Author Contributions: Truong Ngoc Minh and Tran Dang Xuan conceived the idea and wrote the manuscript. Ateeque Ahmad confirmed the chemcial strutures of momilactones A and B. Abdelnaser Abdelghany Elzaawely, Truong Mai Van, and Rolf Teschke revised the manuscript.

Acknowledgments: The authors appreciate Kobayashi International Scholarship Foundation for providing Truong Ngoc Minh a scholarship. Thanks also due to Kume Sangyo, Hiroshima prefecture, Japan. Nguyen Van Quan, Phung Thi Tuyen, Do Tan Khang, Truong Thi Tu Anh, and Yusuf Adriana are appreciated for their assistance to this research.

Conflicts of Interest: The authors declare no conflict of interest.

\section{References}

1. Abbas, A.; Ansumali, S. Global potential of rice husk as a renewable feedstock for ethanol biofuel production. Bioenergy Res. 2010, 3, 328-334. [CrossRef]

2. Li, Y.; Ding, X.; Guo, Y.; Rong, C.; Wang, L.; Qu, Y.; Ma, X.; Wang, Z. A new method of comprehensive utilization of rice husk. J. Hazard. Mater. 2011, 186, 2151-2156. [CrossRef] [PubMed]

3. Lu, Q.; Yang, X.L.; Zhu, X.F. Analysis on chemical and physical properties of bio-oil pyrolyzed from rice husk. J. Anal. Appl. Pyrol. 2008, 82, 191-198. [CrossRef]

4. Salanti, A.; Zoia, L.; Orlandi, M.; Zanini, F.; Elegir, G. Structural characterization and antioxidant activity evaluation of lignins from rice husk. J. Agric. Food Chem. 2010, 58, 10049-10055. [CrossRef] [PubMed]

5. Bhattacharrya, S.C. Viability of off-grid electricity supply using rice husk: A case study from South Asia. Biomass Bioenergy 2014, 68, 44-54. [CrossRef]

6. Delbecq, F.; Wang, Y.; Len, C. Conversion of xylose, xylan and rice husk into furfural via betaine and formic acid mixture as novel homogeneous catalyst in biphasicsystem by microwave-assisted dehydration. J. Mol. Catal. A Chem. 2016, 423, 520-525. [CrossRef]

7. Krishnani, K.K.; Meng, X.; Christodoulatos, C.; Boddu, V.M. Biosorption mechanism of nine different heavy metals onto biomatrix from rice husk. J. Hazard. Mater. 2008, 153, 1222-1234. [CrossRef] [PubMed]

8. D'Souza, S.F.; Godbole, S.S. Immobilization of invertase on rice husk using polyethyenimine. J. Biochem. Biophys. Methods 2002, 52, 59-63. [CrossRef]

9. Zhang, H.; Zhao, X.; Ding, X.; Lei, H.; Chen, X.; An, D.; Li, Y.; Wang, Z. A study on the consecutive preparation of D-xylose and pure superfine silica from rice husk. Bioresour. Technol. 2010, 101, 1263-1267. [CrossRef] [PubMed]

10. Kalderis, D.; Bethanis, S.; Paraskea, P.; Diamadopoulos, E. Production of activated carbon from bagasse and rice husk by a single-stage chemical activation method at low retention times. Bioresour. Technol. 2008, 99, 6809-6816. [CrossRef] [PubMed]

11. Kennedy, J.L.; Vijaya, J.J.; Sekaran, G. Effect of two-stage process on the preparation and characterization of porous carbon composite from rice husk by phosphoric acid activation. Ind. Eng. Chem. Res. 2004, 43, 1832-1838. [CrossRef]

12. Jain, A.; Rao, T.R.; Sambi, S.S.; Grover, P.D. Energy and chemicals from rice husk. Biomass Bioenergy 1995, 7, 1-6. [CrossRef]

13. Guo, Y.; Yu, K.; Wang, Z.; Xu, H. Effects of activation conditions on preparation of porous carbon from rice husk. Carbon 2003, 41, 1645-1648. [CrossRef]

14. Kato, T.; Kabuto, C.; Sasaki, N.; Tsunagawa, M.; Aizawa, H.; Fujita, K.; Kato, Y.; Kitahara, Y. Momilactones, growth inhibitors from rice, Oryza sativa L. Tetrahedron Lett. 1973, 39, 3861-3864. [CrossRef]

15. Kato, T.; Tsunakawa, M.; Sasaki, N.; Aizawa, H.; Fujita, K.; Kitahara, Y.; Takahashi, N. Growth and germination inhibitors in rice husk. Phytochemistry 1977, 16, 45-48. [CrossRef]

16. Kato-Noguchi, H.; Ota, K.; Ino, T. Release of momilactone A and B from rice plants into the rhizosphere and its bio-activities. Allelopathy J. 2008, 22, 321-328. 
17. Kato-Noguchi, H.; Ino, T.; Ota, K. Secretion of momilactone A from rice roots to the rhizosphere. J. Plant Physiol. 2008, 165, 691-696. [CrossRef] [PubMed]

18. Fukuta, M.; Xuan, T.D.; Deba, F.; Tawata, S.; Khanh, T.D.; Chung, I.M. Comparative efficacies in vitro of antibacterial, fungicidal, antioxidant, and herbicidal activities of momilatones A and B. J. Plant Interact. 2007, 2, 245-251. [CrossRef]

19. Xuan, T.D.; Minh, T.N.; Anh, L.H.; Khanh, T.D. Allelopathic momilactones A and B are implied in rice drought and salinity tolerance, not weed resistance. Agron. Sustain. Dev. 2016, 36, 52. [CrossRef]

20. Cho, J.Y.; Moon, J.H.; Seong, K.Y.; Park, K.H. Antimicrobial activity of 4-hydroxybenzoic acid and trans-4-hydroxycinnamic acid isolated and identified from rice hull. Biosci. Biotechnol. Biochem. 1998, 62, 2273-2276. [CrossRef] [PubMed]

21. Ramarathnam, N.; Osawa, T.; Namiki, M.; Kawasiki, S. Chemical studies on novel rice hull antioxidants. 1. Isolation, fractionation, and partial characterization. J. Agric. Food Chem. 1988, 36, 732-737. [CrossRef]

22. Ramarathnam, N.; Osawa, T.; Namiki, M.; Kawasiki, S. Chemical studies on novel rice hull antioxidants. 2. Identification of isovitexin, a C glycosyl flavonoid. J. Agric. Food Chem. 1989, 37, 316-319. [CrossRef]

23. Wu, K.; Zhang, W.; Paul, B.A.; Richard, J.E.; Abdulwahab, M.S.; Jacob, L. Antioxidant properties of wild rice. J. Agric. Food Chem. 1994, 42, 34-37. [CrossRef]

24. Saha, B.C.; Iten, L.B.; Cotta, M.A.; Wu, Y.W. Dilute acid pretreatment, enzymatic saccharification, and fermentation of rice hulls to ethanol. Biotechnol. Prog. 2005, 21, 816-822. [CrossRef] [PubMed]

25. Xuan, T.D.; Tsuzuki, E.; Terao, H.; Matstuo, M.; Khanh, T.D.; Murayama, S.; Hong, N.H. Alfalfa, rice by-products and their incorporation for weed control in rice. Weed Biol. Manag. 2003, 3, 137-144. [CrossRef]

26. Xuan, T.D.; Tawata, S.; Khanh, T.D.; Chung, I.M. Biological control of weeds and plant pathogens in paddy rice by exploiting plant allelopathy: An overview. Crop Prot. 2005, 24, 197-206. [CrossRef]

27. Khanh, T.D.; Chung, M.I.; Xuan, T.D.; Tawata, S. The exploitation of crop allelopathy in sustainable agricultural production. J. Agron. Crop Sci. 2005, 191, 172-184. [CrossRef]

28. Minh, T.N.; Khang, D.T.; Tuyen, P.T.; Minh, L.T.; Anh, L.H.; Quan, N.V.; Ha, P.T.T.; Quan, N.T.; Toan, N.P.; Elzaawely, A.A.; et al. Phenolic compounds and antioxidant activity of Phalaenopsis orchid hybrids. Antioxidants 2016, 5, 31. [CrossRef] [PubMed]

29. Minh, T.N.; Tuyen, P.T.; Khang, D.T.; Quan, N.V.; Ha, P.T.T.; Quan, N.T.; Yusuf, A.; Fan, X.; Van, T.M.; Khanh, T.D.; et al. Potential use of plant wastes of moth orchid [Phalaenopsis Sogo Yukidian 'V3'] as an antioxidant source. Foods 2017, 6, 85. [CrossRef] [PubMed]

30. Quettier-Deleu, C.; Gressier, B.; Vasseur, J.; Dine, T.; Brunet, C.; Luyckx, M.; Cazin, M.; Cazin, J.-C.; Bailleul, F.; Trotin, F. Phenolic compounds and antioxidant activities of buckwheat (Fagopyrum esculentum Moench) hulls and flour. J. Ethnopharmacol. 2000, 72, 35-42. [CrossRef]

31. Elzaawely, A.A.; Tawata, S. Antioxidant activity of phenolic rich fraction obtained from Convolvulus arvensis L. leaves grown in Egypt. J. Crop Sci. 2012, 4, 32-40. [CrossRef]

32. Xuan, T.D.; Gu, G.G.; Minh, T.N.; Quy, T.N.; Khanh, T.D. An overview of chemical profiles, antioxidant and antimicrobial activities of commercial vegetable edible oils marketed in Japan. Foods 2018, 7, 21. [CrossRef] [PubMed]

33. Tuyen, P.T.; Xuan, T.D.; Khang, D.T.; Ahmad, A.; Quan, N.V.; Anh, T.T.T.; Anh, L.H.; Minh, T.N. Phenolic compositions and antioxidant properties in bark, flower, inner skin, kernel and leaf extracts of Castanea crenata Sieb. et Zucc. Antioxidants 2017, 6, 31. [CrossRef] [PubMed]

34. Tuyen, P.T.; Khang, D.T.; Ha, P.T.T.; Hai, T.N.; Elzaawely, A.A.; Xuan, T.D. Antioxidant capacity and phenolic contents of three Quercus species. Int. Lett. Nat. Sci. 2016, 54, 85-99. [CrossRef]

35. Lim, J.S.; Manan, Z.A.; Alwi, S.R.W.; Hashim, H. A review on utilisation of biomass from rice industry as a source of renewable energy. Renew. Sustain. Environ. Res. 2012, 16, 3084-3094. [CrossRef]

36. Rajanna, S.K.; Vinjamur, M.; Mukhopadhyay, M. Mechanism for formation of hollow and granular silica aerogel microspheres from rice husk ash for drug delivery. J. Non-Cryst. Solids 2015, 429, 226-231. [CrossRef]

37. Herna'ndez, M.S.; Herna'ndez, C.S.; Fuentes, A.G.; Elorza, E.; Carrera-Rodrı'guez, M.; Alquiza, M.J.P. Silica from rice husks employed as drug delivery for folic acid. J. Sol-Gel Sci. Technol. 2014, 71, 514-521. [CrossRef]

38. Kim, S.J.; Park, H.R.; Park, E.; Lee, S.C. Cytotoxic and antitumor activity of momilactone B from rice hulls. J. Agric. Food Chem. 2007, 55, 1702-1706. [CrossRef] [PubMed] 
39. Mennan, H.; Ngouajio, M.; Sahin, M.; Isik, D.; Kaya, A.E. Quantification of momilactone B in rice hulls and the phytotoxic potential of rice extracts on the seed germination of Alisma plantago-aquatica. Weed Biol. Manag. 2012, 12, 29-39. [CrossRef]

40. Anda, M.; Shamshuddin, J. Changes in chemistry of rice husk compost and its effect on negative charge and nutrient content of a chemically degraded oxisol. Commun. Soil Sci. Plant Anal. 2015, 46, 1419-1442. [CrossRef] 